\title{
Patient Table Relationship
}

National Cancer Institute

\section{Source}

National Cancer Institute. Patient Table Relationship. NCI Thesaurus. Code C69236.

The orientation of a patient in relation to the head of the table. 